\title{
Differential Effects of Antihypertensive Drugs on Renal and Glomerular Hemodynamics and Injury in the Chronic Nitric-Oxide-Suppressed Rat
}

\author{
Xiaoyan Zhou Edward D. Frohlich \\ Hypertension Research Laboratories, Ochsner Clinic Foundation, New Orleans, La., USA
}

\section{Key Words}

Hemodynamics · Glomerulosclerosis · Rat model ·

Nitric oxide synthase inhibition

\begin{abstract}
Background/Aims: Prolonged nitric oxide synthase (NOS) inhibition with $\mathrm{N}^{\omega}$-nitro-L-arginine methylester in normotensive and hypertensive rats has been demonstrated to produce severe systemic and glomerular hypertension with glomerular sclerosis, and these changes have become a useful experimental model of hypertensive nephrosclerosis. This review summarizes data from our serial studies as well as work of others who are also investigating the effects of the commonly used antihypertensive drugs (including calcium antagonist, angiotensin-converting enzyme inhibitor, angiotensin II type 1 receptor blocker, aldosterone antagonist and thiazide diuretic) on renal and glomerular hemodynamics, renal function and glomerular histopathology using this model. Methods: A Medline search was performed to identify the relevant literature describing renal effects of antihypertensive drugs in models of hypertension and nephrosclerosis produced or exacerbated by NOS inhibition. Results: Existing data have indicated that most of
\end{abstract}

these drug classes have produced dramatic renoprotective effects, structurally or functionally, on nephrosclerosis induced by prolonged NOS inhibition. Conclusion: This review of experimental studies has provided strong evidence supporting the clinical benefits of antihypertensive drugs for hypertensive patients with renal impairment particularly those with endothelial dysfunction associated with NOS deficiency.

Copyright (C) 2005 S. Karger AG, Basel

\section{Introduction}

Nitric oxide is generated by the enzyme nitric oxide synthase (NOS) in the cardiovascular, renal, central nervous, gastrointestinal and immune systems [1-4]. It plays a critical role in regulating endothelial function $[4,5]$, systemic, renal and coronary hemodynamics [4-6], platelet adhesion and aggregation [7], cardiomyocyte hypertrophy [8] and vascular smooth muscle cell proliferation and fibrosis [9]. Chronic NOS inhibition with $\mathrm{N}^{\omega}$-nitro$L$-arginine methylester ( $L$-NAME) has been shown to activate both the systemic and local renal renin-angiotensin systems [10-13] and to increase sympathetic nerve activity $[11,14]$, thereby promoting persistent hypertension

\section{KARGER \\ Fax +4161306 1234 E-Mail karger@karger.ch} www.karger.com
(C) 2005 S. Karger AG, Basel 0250-8095/05/0252-0138\$22.00/0

Accessible online at: www.karger.com/ajn
Edward D. Frohlich, MD, Alton Ochsner Distinguished Scientist

Ochsner Clinic Foundation

1516 Jefferson Highway

New Orleans, LA 70121 (USA)

Tel. +1 504842 3700, Fax +1 504842 3258, E-Mail efrohlich@ochsner.org 
through cardiovascular and renal damage. In normotensive rats, prolonged NOS inhibition results in sustained systemic and glomerular hypertension with proteinuria and focal glomerular sclerosis [15], marked renal vasoconstriction, arteriolar hypertrophy and focal arteriolar obliteration, and renal interstitial inflammatory responses [16]. In hypertensive rats, studies from our laboratory $[10,17,18]$ and others $[19,20]$ have shown that prolonged NOS inhibition impaired renal and glomerular hemodynamics by significant glomerular arteriolar constriction and produced severe hypertensive nephrosclerosis in association with reduced glomerular tuft area, glomerular cell loss and apoptosis, tubular atrophy and interstitial fibrosis. Moreover, chronic NOS inhibition exacerbated preexistent hypertension to develop malignant hypertension and severe renal injury, even a high mortality [19]. These findings suggest that suppressed $\mathrm{NO}$ generation has emerged as a sufficient risk factor in the severe hypertensive nephrosclerosis process. Furthermore, prolonged NOS inhibition with $L$-NAME in younger (20-week-old) adult spontaneously hypertensive rats (SHR) produced pathophysiological alterations that were similar to naturally occurring nephrosclerosis in the aged SHR [17, 18, 21].

A number of experimental models have been employed for investigating progression of chronic renal disease in the past decades [22-28]. These models have usually involved surgical renal ablation of one or both kidneys with or without additional salt loading, steroidal administration or renal infarction; none of them have involved the natural development of renal dysfunction in animals with genetic hypertension [18]. Of particular note, a commonly used experimental model of $5 / 6$ renal ablation (right uninephrectomy and infarction of two thirds of the left kidney), over time, develop proteinuria and progressive glomerulosclerosis of the initial normal remnant nephrons, which is hemodynamically characterized by systemic hypertension, glomerular arteriolar dilation, glomerular hypertension and consequently hyperfiltration [24, 25]. Obviously, this remnant kidney model is significantly distinct from the $L$-NAME/SHR model described above. Moreover, that remnant kidney model involves extreme reduction in renal mass, an initial deficit in renal function far beyond that in essential hypertensive patients who may slowly and progressively develop renal dysfunction.

For these reasons, the prolonged NOS-inhibited rat has become a useful experimental model of hypertensive nephrosclerosis that mimics alteration of a naturally occurring physiological process. Unfortunately, only a small number of studies have investigated the effects of various pharmacological interventions on nephrosclerosis, structurally and functionally, in this experimental model. This report reviews data from our serial studies and others involving effects of several classes of antihypertensive agents on the prevention, development, progression and even reversal of nephrosclerosis induced by prolonged NOS inhibition.

\section{Calcium Antagonists}

The effects of calcium antagonists on the kidney have been widely investigated in vitro in the isolated perfused rat kidney [29-31] and blood-perfused juxtamedullary nephrons [32-34], and in vivo in experimental models including the SHR $[35,36]$, deoxycorticosterone salt-hypertensive [37, 38] and remnant-kidney rats [39-41]. However, some of these findings are contradictory and might be explained by differences in the structure, pharmacology, dosing profiles and duration of administration of the drugs as well as the experimental models themselves.

Several studies have been carried out in the chronic NOS-inhibited rat model to investigate the effects of various calcium antagonists on renal function and histopathology (table 1). Ribeiro et al. [42] found that MunichWistar rats, treated with $L$-NAME, exhibited extremely variable plasma renin activity, glomerular tuft collapse and renal interstitial fibrosis. Simultaneous nifedipine treatment normalized the dispersion of plasma renin levels while preventing renal morphological abnormalities. Navarro-Cid et al. [43] demonstrated that diltiazem normalized proteinuria induced by $L$-NAME in SpragueDawley rats, and Akuzawa et al. [44] reported that another calcium antagonist, amlodipine, ameliorated urinary albumin excretion and nephrosclerosis induced by $L$-NAME in Wistar rats. Another study, by Mandarimde-Lacerda and Pereira [45], demonstrated that verapamil efficiently prevented $L$-NAME-induced glomerular sclerosis/hypertrophy and tubular remodeling in Wistar rats. The above-mentioned studies were performed in the $L$-NAME-treated normotensive rat, and all these calcium antagonists provided beneficial effects on renal function and histopathology. Studies performed in the $L$ NAME-treated hypertensive rat model also showed favorable effects of calcium antagonists on renal injury. For example, Qiu et al. [46] documented that mibefradil prevented the development of proteinuria and decreased creatinine clearance while preventing renal structural dam- 
Table 1. Renal outcomes of various calcium antagonists in the chronic nitric-oxide-suppressed rat

\begin{tabular}{|c|c|c|c|}
\hline $\begin{array}{l}\text { Calcium } \\
\text { antagonist }\end{array}$ & Experimental model & Renal outcomes & Investigators \\
\hline Nifedipine & $L$-NAME/Wistar rats & Prevented glomerular tuft collapse and renal interstitial fibrosis & Ribeiro et al. [42] \\
\hline Diltiazem & $\begin{array}{l}L \text {-NAME/Sprague- } \\
\text { Dawley rats }\end{array}$ & Normalized proteinuria & Navarro-Cid et al. [43] \\
\hline \multirow[t]{2}{*}{ Amlodipine } & $L$-NAME/Wistar rats & Ameliorated urinary albumin excretion and nephro-sclerosis & Akuzawa et al. [44] \\
\hline & $L$-NAME/SHR & $\begin{array}{l}\text { Improved glomerular dynamics and reduced glomerular and } \\
\text { arteriolar injury scores }\end{array}$ & Nakamura et al. [50] \\
\hline Verapamil & $L$-NAME/Wistar rats & Prevented glomerular sclerosis/hypertrophy and tubular remodeling & $\begin{array}{l}\text { Mandarim-de-Lacerda } \\
\text { and Pereira [45] }\end{array}$ \\
\hline \multirow[t]{2}{*}{ Mibefradil } & $L$-NAME/SHR & $\begin{array}{l}\text { Prevented proteinuria, decreased creatinine clearance and protected } \\
\text { renal structure }\end{array}$ & Qiu et al. [46] \\
\hline & $L-\mathrm{NAME} / \mathrm{SHR}$ & $\begin{array}{l}\text { Improved glomerular dynamics and reduced glomerular and } \\
\text { arteriolar injury scores }\end{array}$ & Nakamura et al. [50] \\
\hline Efonidipine & $L-\mathrm{NAME} / \mathrm{SHR}$ & $\begin{array}{l}\text { Prevented severe proteinuria and nephrosclerosis, inhibited } \\
\text { glomerular cell apoptosis and proliferation }\end{array}$ & Watanabe et al. [47] \\
\hline Felodipine & $L$-NAME/SHR & $\begin{array}{l}\text { Improved glomerular dynamics and reduced glomerular and } \\
\text { arteriolar injury scores }\end{array}$ & $\begin{array}{l}\text { Francischetti } \\
\text { et al. [49] }\end{array}$ \\
\hline Cilnidipine & $L$-NAME/SHR & $\begin{array}{l}\text { Improved renal pathophysiology and inhibited apoptosis and } \\
\text { glomerular cellular proliferation }\end{array}$ & Zhou et al. [51] \\
\hline
\end{tabular}

age as assessed by scoring glomerular, tubulointerstitial and vascular lesions in the $L$-NAME/SHR model. Watanabe et al. [47] reported that another calcium antagonist, efonidipine, also prevented severe proteinuria and nephrosclerosis and significantly inhibited the increase in glomerular cell apoptosis index and the proliferative cell nuclear antigen index in the $L$-NAME/SHR model.

The actions of calcium antagonists on afferent and efferent arteriolar resistance had been an intriguing topic. Most traditional calcium antagonists have been shown to dilate afferent arterioles preferentially and to promote glomerular hypertension; however, newly developed calcium antagonists dilate both afferent and efferent arterioles and ameliorate glomerular hypertension [48]. In the past several years, we have carefully studied the effects of three different types of calcium antagonists on renal hemodynamics and glomerular dynamics in the $L$-NAME/ SHR model using classical renal micropuncture techniques, which include felodipine and amlodipine (L type calcium antagonists), mibefradil (an L and T type calcium antagonist) and cilnidipine (an $\mathrm{L}$ and $\mathrm{N}$ type calcium antagonist) [49-51]. Each of these three types of calcium antagonists dilated not only the afferent but also the ef- ferent arterioles, improved single-nephron plasma flow and increased single-nephron glomerular filtration rate in SHR co-treated with $L$-NAME (representing the preventive effects of calcium antagonists, fig. 1a-c) or post-treated after $L$-NAME (signifying the reversing effects of calcium antagonists, fig. 2a-c). They also prevented and reversed the glomerular and arteriolar injury in this L-NAME/SHR model (fig. 1d, 2d). In summary, although there were some minor differences in the responses among these calcium antagonists, they did not differ substantially with respect to their overall renoprotective effects.

Thus, in general, calcium antagonists, regardless of their subclasses, produced dramatic protective effects on renal pathophysiology in this particular experimental model of chronic NOS inhibition in normotensive or hypertensive rats. Their precise mechanisms remain unclear although inhibition of angiotensin II or norepinephrine may very well participate. 


\section{Angiotensin-Converting Enzyme Inhibitor and Angiotensin II Type 1 Receptor Blocker}

Renin-angiotensin system inhibition by an angiotensin-converting enzyme inhibitor (ACE-I) or angiotensin II type 1 receptor blocker (ARB) has distinct renoprotective effects in animals and humans [52-54]. Their favorable actions are believed to arise from inhibiting angiotensin II generation or directly inhibiting angiotensin II type 1 receptor stimulation [55-57]. However, ACE inhibition also reduces degradation of bradykinin [58-60], a potent vasodilator [61], which promotes selective efferent arteriolar dilatation during ACE inhibition [62]. On the other hand, the angiotensin II type 1 receptor antagonism may promote type 2 receptor upregulation $[60,63]$ and thereby modulates the opposing effect of angiotensin II type 1 receptor on arterial pressure [64, 65]. Furthermore, the angiotensin II type 2 receptor may also exert an antiproliferative effect, counteracting the growth action of angiotensin II type 1 receptor [66-71]. Therefore, these potential effects might constitute differential outcomes for these two classes of renin-angiotensin system inhibitors on renal diseases. However, which type of angiotensin II inhibitor confers greater renoprotection remains unresolved.

In experimental models of chronic renal disease, most studies have reported that ACE-I and ARB afforded similar beneficial effects including amelioration of proteinuria and glomerulosclerosis, suggesting that their key role is angiotensin II inhibition [72]. A few reports have suggested greater renoprotection with the ARB candesartan than with ACE-I enalapril $[73,74]$. Data from recent clinical trials suggest that, in nondiabetic renal disease and in type 2 diabetes with microalbuminuria, ACE-I and ARB share a similar renoprotective effect [75-77]. Nevertheless, combined treatment with the ACE-I and ARB showed enhanced renoprotective benefit in patients with nondiabetic renal disease $[78,79]$ or both type 1 and type 2 diabetes [76, 80, 81]. However, taken together, comparative data on renal protective effects of ACE-I and $\mathrm{ARB}$ remain insufficient to permit the arrival at a conclusion as to which of these two types of agents may be better.

We have exploited the $L$-NAME/SHR model of severe hypertensive nephrosclerosis to investigate the effects of ACE-I and ARB on the prevention, development, progression and even reversal of nephrosclerosis. Our earlier results demonstrated that the ACE inhibitors quinapril, enalapril or lisinopril dilated both afferent and efferent arterioles, reduced glomerular capillary hydrostatic pres- sure and thereby prevented and reversed the development of proteinuria and glomerular sclerosis [49, 82-84] (fig. 3a-d). We have also designed a study to determine potentially differential effects between candesartan and enalapril on systemic, renal and glomerular hemodynamics and pathological changes in SHR with L-NAME-exacerbated nephrosclerosis [84]. Furthermore, we also investigated the contribution of bradykinin to the renal effects of enalapril in that study. Our data clearly showed that angiotensin II type 1 receptor antagonism and ACE inhibition had very similar renopreventive effects and that the ACE inhibition of bradykinin degradation provided little evidence in support of a bradykinin renoprotective action in this model. We therefore concluded that $\mathrm{ARB}$ and ACE-I were equally effective in renoprotection in the $L$-NAME/SHR model as in other experimental models [72]. Notwithstanding, it seems reasonable to conclude that angiotensin II plays a crucial role in influencing glomerular pathophysiological changes, whereas bradykinin only participated partially in reducing arterial pressure. Moreover, bradykinin had little effect on renal hemodynamics, glomerular dynamics, renal function and histopathology.

In addition, the effects of ACE-I and ARB have been explored in the $L$-NAME-treated normotensive rat model. In general, the ACE inhibitors such as ramipril [85], quinapril [86], and imidapril [87], and the ARB (e.g. losartan) [88-90] significantly prevented hypertension and renal functional as well as morphological damage induced by prolonged NOS inhibition. Furthermore, one comparative study demonstrated that severe histological and biochemical injuries induced by $L$-NAME were equally ameliorated by either ACE-I or ARB [91].

Data from our laboratory and others (table 2) using the prolonged NOS inhibition model further confirmed the renoprotective effects of ACE-I and ARB. The comparative results of ACE-I and ARB in $L$-NAME-treated hypertensive and normotensive rats provided strong evidence for the equivalent effectiveness of these two classes of agents with respect to renoprotection. Unfortunately, detailed dose-response effects have not been explored, and combination of these two agents dealing with their renal benefits has not been examined in this model. It is possible, however, that dual blockade of the renin-angiotensin system with an ACE-I and an ARB could offer further benefit beyond the value of either agent when used alone, which must be awaited to be explored. 


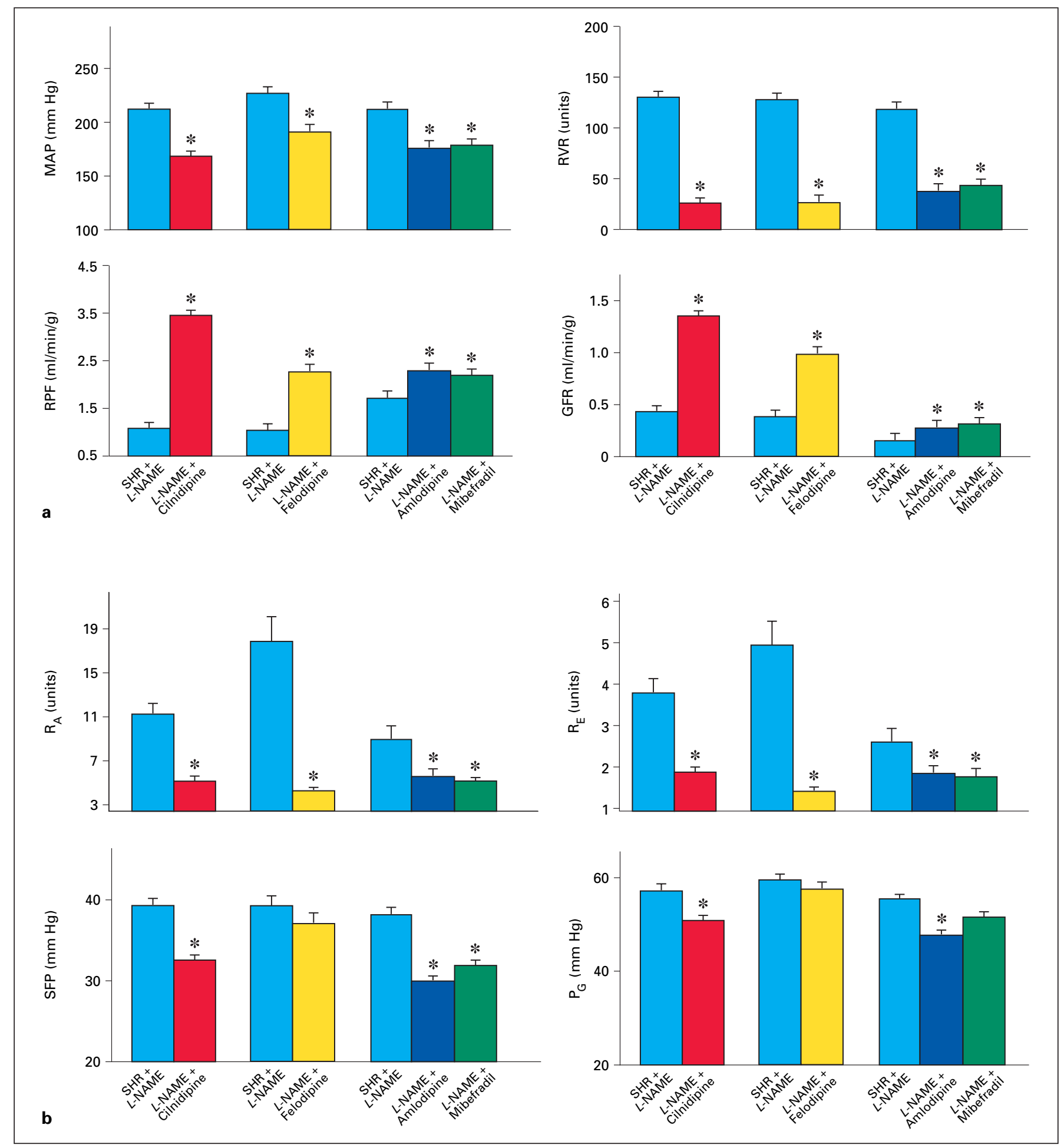

Fig. 1. Co-treatment with $L-N A M E$ and 3 types of calcium antagonists for 3 weeks. $* \mathrm{p}<0.05$ at least. a Effects on renal hemodynamics. MAP = Mean arterial pressure; $\mathrm{RVR}=$ renal vascular resistance; $\mathrm{RPF}=$ renal plasma flow; GFR = glomerular filtration rate. $\mathbf{b}$, $\mathbf{c}$ Effects on glomerular dynamics. $\mathrm{R}_{\mathrm{A}}$ and $\mathrm{R}_{\mathrm{E}}=$ Afferent and efferent glomerular arteriolar resistances, respectively; $\mathrm{SFP}=$ stop-flow pressure; $\mathrm{P}_{\mathrm{G}}=$ glomerular capillary pressure; SNPF = single-nephron plasma flow; SNGFR = single-nephron glomerular filtration rate; SNFF = single-nephron filtration fraction; $\mathrm{K}_{\mathrm{f}}=$ ultrafiltration coefficient. $\mathbf{d}$ Effects on renal function and pathology. GIS = Glomerular injury score; AIS = arteriolar injury score. 


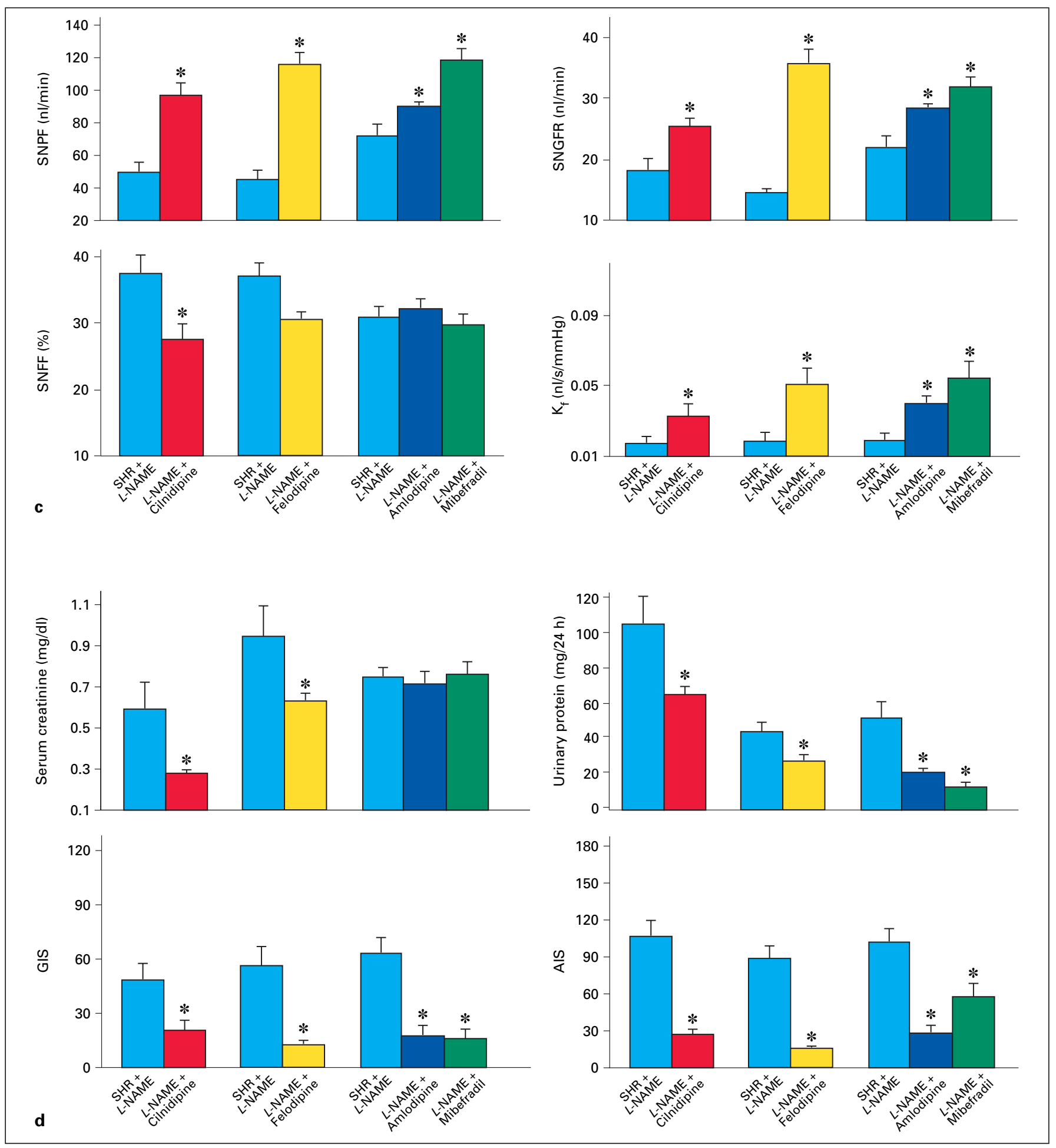




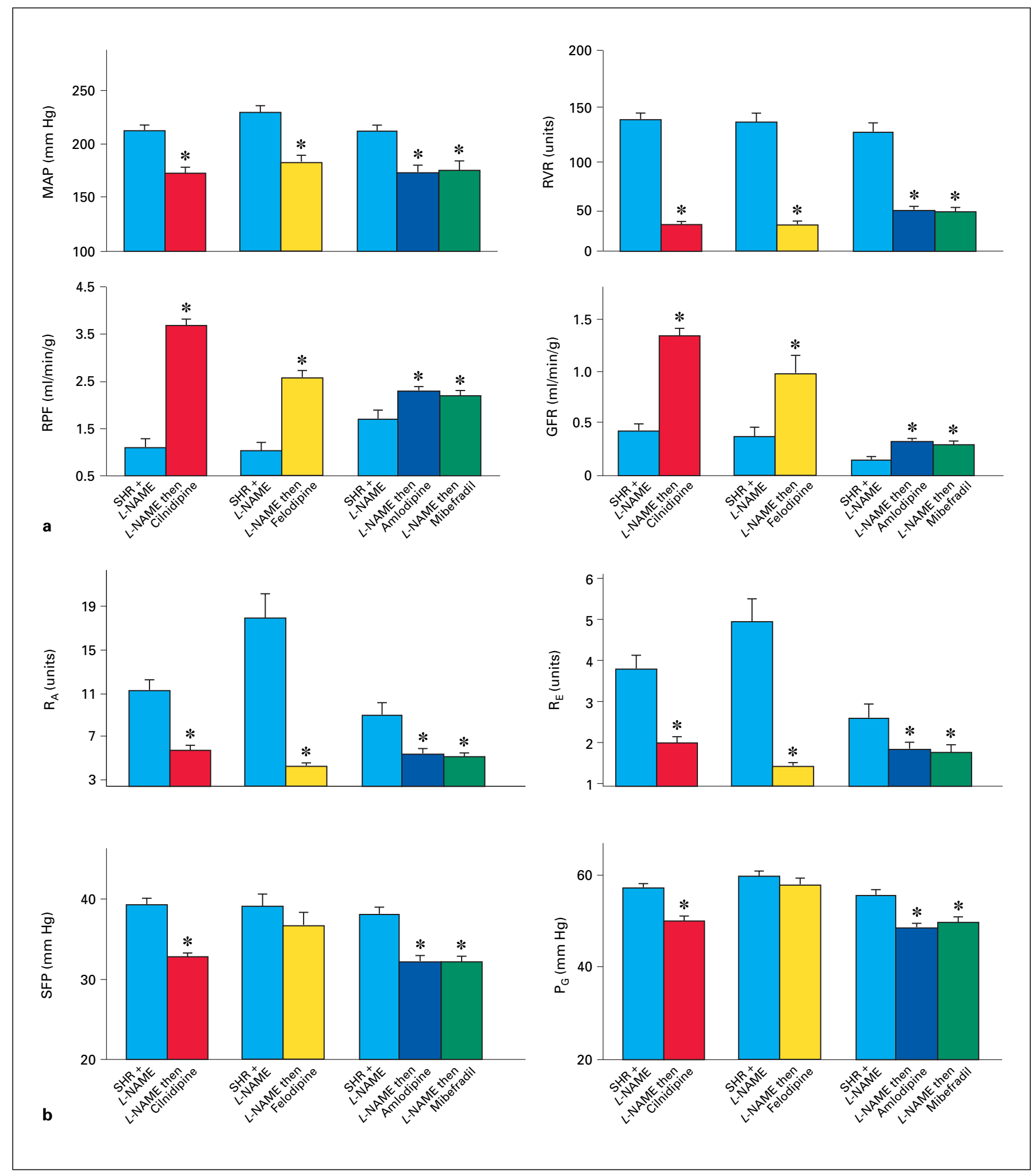

Fig. 2. Posttreatment with 3 types of calcium antagonists after $L$-NAME (i.e. $L$-NAME for initial 3 weeks followed by a subsequent 3 weeks of calcium antagonist treatment). $* \mathrm{p}<0.05$ at least. For explanation of abbreviations, see figure 1. a Effects on renal hemodynamics. b, $\mathbf{c}$ Effects on glomerular dynamics. d Effects on renal function and pathology. 


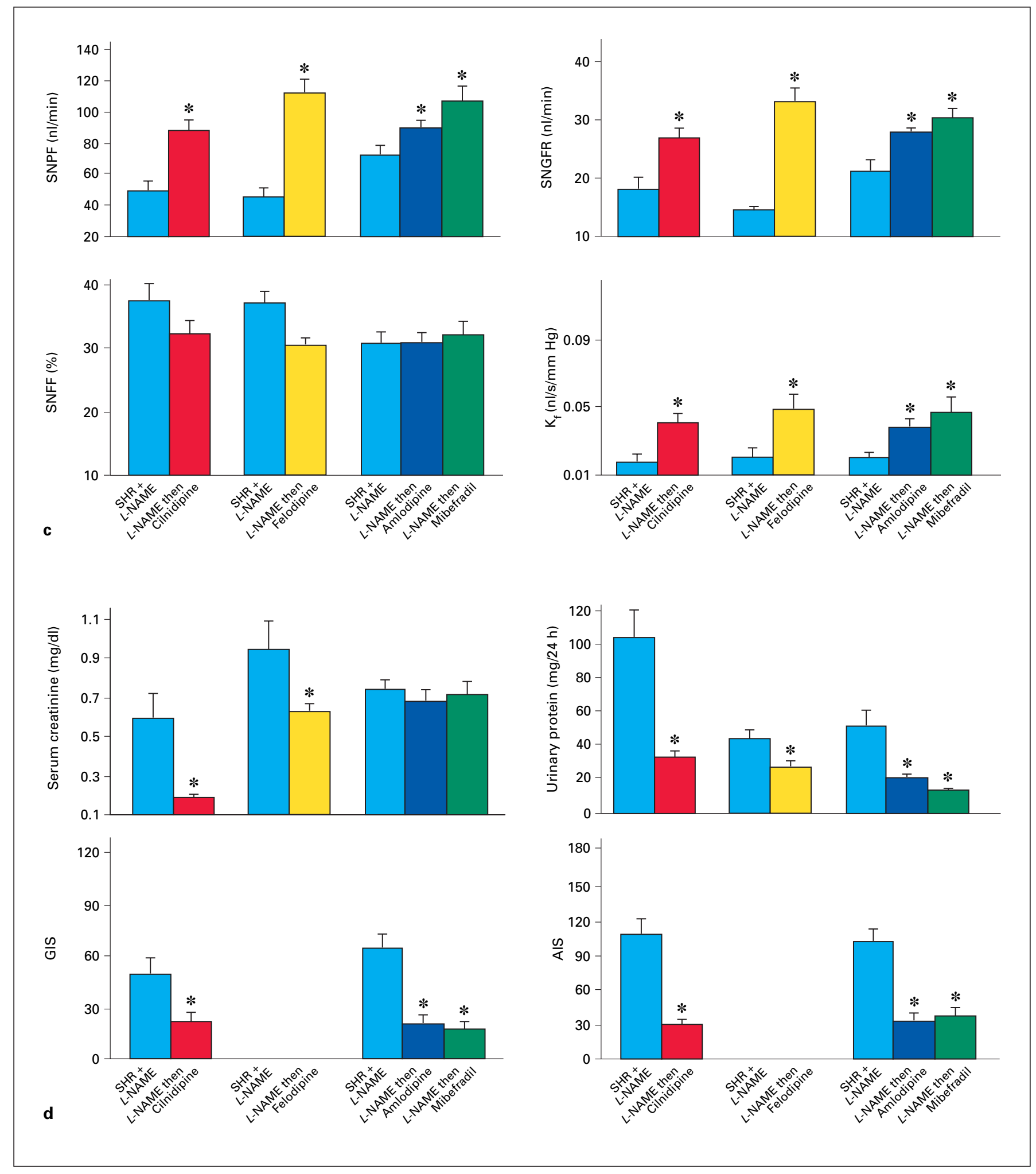




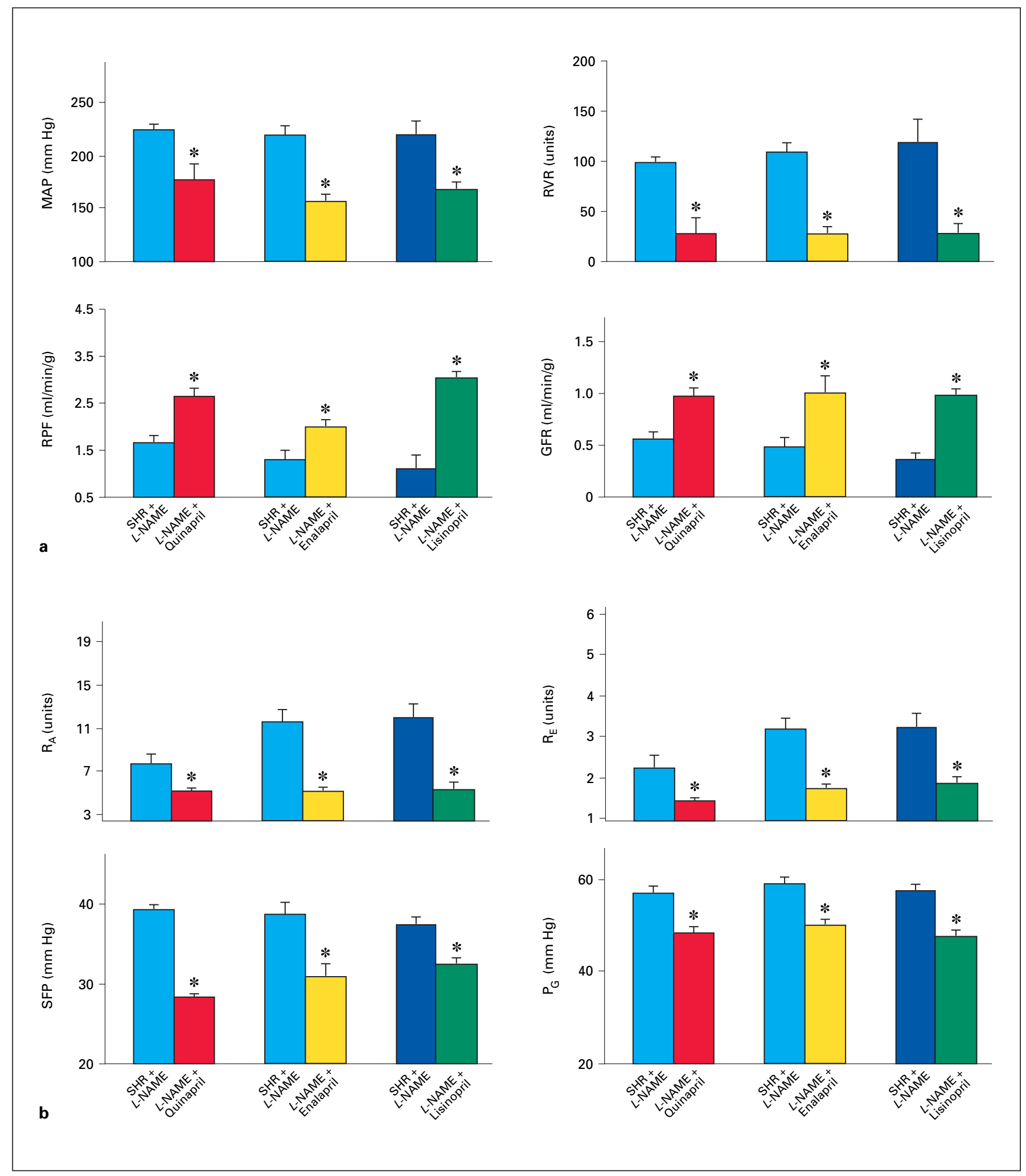

Fig. 3. Co-treatment with $L-N A M E$ and 3 ACE inhibitors for 3 weeks. $*$ p $<0.05$ at least. For explanation of abbreviations, see figure 1. a Effects on renal hemodynamics. b, c Effects on glomerular dynamics. d Effects on renal function and pathology. 


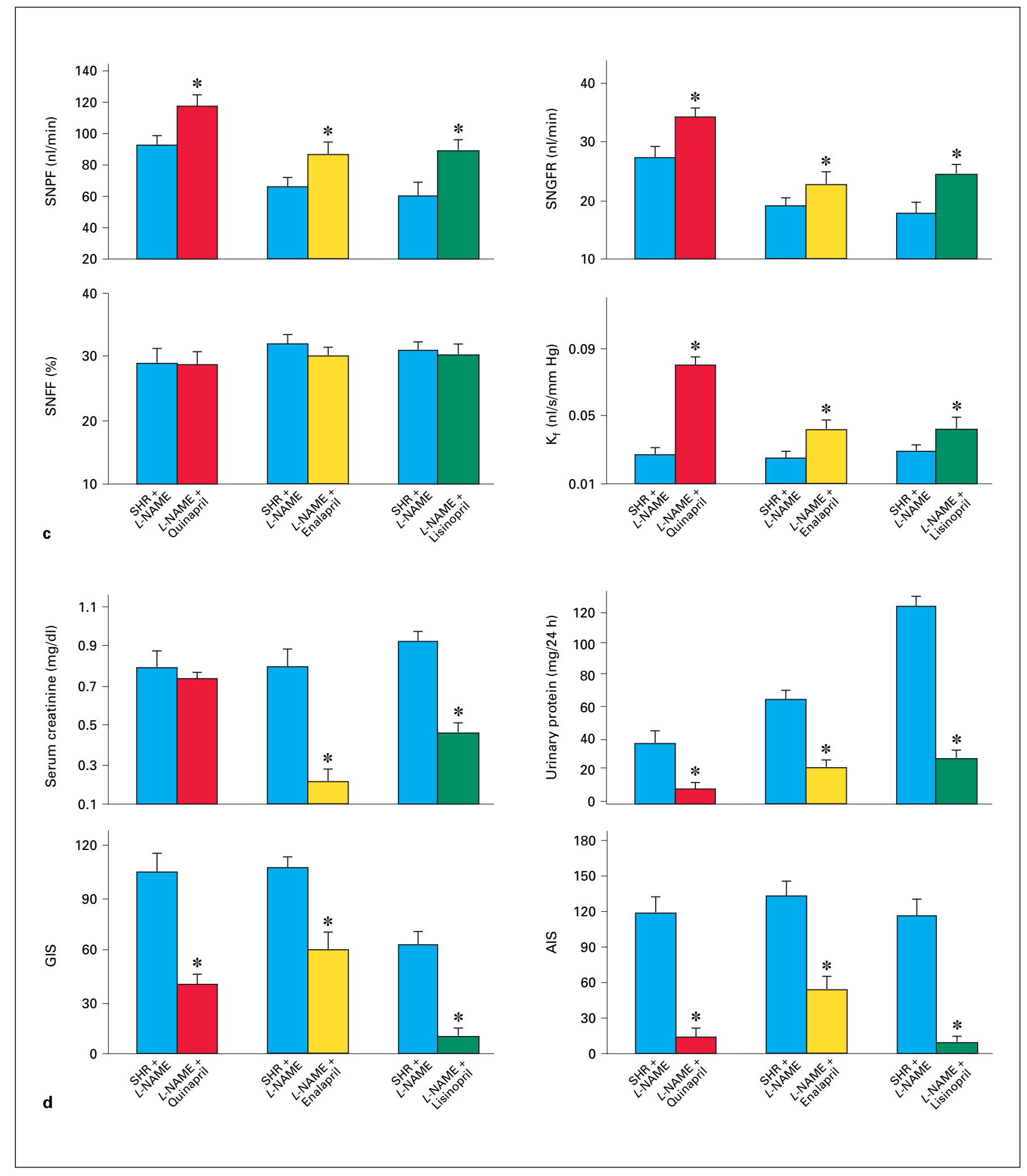


Table 2. Renal outcomes of different ACE-I or ARB in the chronic nitric-oxide-suppressed rat

\begin{tabular}{|c|c|c|c|}
\hline ACE-I or ARB & Experimental model & Renal outcomes & Investigators \\
\hline \multirow[t]{2}{*}{ Quinapril } & $L$-NAME/SHR & $\begin{array}{l}\text { Improved glomerular dynamics and reduced glomerular and } \\
\text { arteriolar injury scores }\end{array}$ & Ono et al. [82] \\
\hline & $L$-NAME/Wistar rats & Improved survival & Michel et al. [86] \\
\hline \multirow[t]{2}{*}{ Enalapril } & $L$-NAME/SHR & $\begin{array}{l}\text { Improved glomerular dynamics and reduced glomerular and } \\
\text { arteriolar injury scores }\end{array}$ & $\begin{array}{l}\text { Francischetti et al. [49] } \\
\text { and Nakamura et al. [84] }\end{array}$ \\
\hline & L-NAME/Wistar rats & $\begin{array}{l}\text { Prevented glomerular sclerosis/hypertrophy and tubular } \\
\text { remodeling }\end{array}$ & $\begin{array}{l}\text { Mandarim-de-Lacerda } \\
\text { and Pereira [45] }\end{array}$ \\
\hline Lisinopril & $L$-NAME/SHR & $\begin{array}{l}\text { Improved glomerular dynamics and ameliorated urinary } \\
\text { albumin excretion and nephrosclerosis }\end{array}$ & Zhou et al. [83] \\
\hline Ramipril & $L$-NAME/Wistar rats & Improved renal hemodynamics and renal function & Hropot et al. [85] \\
\hline \multirow[t]{2}{*}{ Imidapril } & $L$-NAME/Wistar rats & Prevented nephrosclerosis & Nakamura et al. [87] \\
\hline & $L$-NAME/Wistar rats & $\begin{array}{l}\text { Ameliorated histological injuries and the increased expression } \\
\text { of transforming growth factor } B\end{array}$ & Kashiwagi et al. [91] \\
\hline \multirow[t]{2}{*}{ Candesartan } & $L$-NAME/SHR & $\begin{array}{l}\text { Improved glomerular dynamics and ameliorated } \\
\text { urinary albumin excretion and nephrosclerosis }\end{array}$ & Nakamura et al. [84] \\
\hline & L-NAME/Wistar rats & $\begin{array}{l}\text { Ameliorated histological injuries and the increased expression } \\
\text { of transforming growth factor } B\end{array}$ & Kashiwagi et al. [91] \\
\hline \multirow[t]{2}{*}{ Losartan } & $L$-NAME/Wistar rats & Normalized glomerular filtration rate & Ribeiro et al. [88] \\
\hline & $\begin{array}{l}\text { L-NAME/Sprague- } \\
\text { Dawley rats }\end{array}$ & Prevented severe renal injury and hypertension & Verhagen et al. [90] \\
\hline
\end{tabular}

\section{Aldosterone Antagonists}

Recently, a number of experimental and clinical reports have demonstrated that aldosterone participates in hypertension and renal injury [92-98] and may be supported further by the antihypertensive and renoprotective effects of aldosterone antagonism [92-94, 96, 97, 99, 100]. In addition, the phenomenon of 'aldosterone escape' has been suggested to participate during ACE-I therapy [101-104]. Accordingly, aldosterone antagonism has been perceived as an important approach in preventing the progression of renal dysfunction in hypertension [105, 106] since it may also enhance the effectiveness of angiotensin II inhibition. Indeed, recent clinical trials including the Randomized Aldactone Evaluation Study [107] and the Eplerenone Post-AMI Heart Failure Efficacy and Survey Study [108] have demonstrated a greater benefit of the co-administration of an aldosterone antagonist with an ACE-I or an ARB in patients with cardiac dysfunction. Whether or not the combination of aldosterone antagonism with angiotensin II inhibition produces supe- rior renal benefits to angiotensin II inhibition therapy alone is, at present, a matter of speculation.

The experimental studies described above were explored in the aldosterone/salt-hypertensive rat [92], remnant-kidney rat [93], stroke-prone SHR [94, 95], LNAME/angiotensin II/NaCl-treated rat [96] and radiation-induced nephrosclerotic rat [97]. One study by Usui et al. [109] reported that prolonged NOS inhibition also increased plasma aldosterone concentration and its mRNA level; however, the effect of aldosterone antagonism on the prolonged NOS-inhibition-induced hypertension and renal damage has been barely investigated.

With this background, we initiated a study designed to test the effects of the aldosterone antagonist eplerenone in $L$-NAME-exacerbated SHR nephrosclerosis and the outcomes of combined therapy of eplerenone with the ACE-I lisinopril to determine whether aldosterone antagonism enhances the effectiveness of ACE inhibition [83]. Our findings demonstrated that an aldosterone antagonist had no effect on systemic, renal hemodynamics and glomerular dynamics; however, it did significantly 
ameliorate the proteinuria and markedly improve glomerular and arteriolar injuries and tubulointerstitial lesions in the $L$-NAME/SHR model. To this end, we suggested that the beneficial effects of eplerenone were most likely achieved through nonhemodynamic effects such as its anti-inflammatory actions [92]. We further found that combined therapy with an aldosterone antagonist and an ACE-I produced no further benefit than with the ACE-I alone on the renal pathophysiological alterations in $L$ NAME/SHR nephrosclerosis. The explanation for the latter unexpected finding remains unresolved, and it is possible that aldosterone escape had not emerged during the 3-week period of our study.

Therefore, existing data suggest that aldosterone plays a deleterious role in the progression of $L$-NAME-induced SHR nephrosclerosis, although angiotensin II may be considered as an essential determinant of inducing the advanced hemodynamic consequences such as systemic and glomerular hypertension as well as renal damage during chronic NOS inhibition [10-13]. Eplerenone, the selective mineralocorticoid receptor antagonist, has afforded favorable renal actions in the experimental model of chronic NOS inhibition.

\section{Thiazide Diuretics}

Since their introduction in the late 1950s, thiazide diuretics have been considered as a major antihypertensive drug class [110]. After being widely used in the major antihypertensive drug trials and clinically for decades, the thiazide diuretics were highlighted in recent clinical trials, the Antihypertensive and Lipid-Lowering Treatment to Prevent Heart Attack Trial [111] and the Second Australian National Blood Pressure Study [112]. Thus, they are currently advised for initiating therapy by the Seventh Report of the Joint National Committee on Prevention, Detection, Evaluation and Treatment of High Blood Pressure [113].

However, although the thiazide diuretics have been demonstrated to be efficacious for preventing stroke and hypertensive cardiovascular disease and decreasing total mortality in numerous clinical trials [111, 114], studies investigating the effects of thiazide diuretics on hypertensive renal damage are scarce in both experimental and clinical settings [115-117]. Of particular note, a prior study from our laboratory evaluated the effects of hydrochlorothiazide on $L$-NAME-induced severe hypertensive nephrosclerosis; the data demonstrated that hydrochlorothiazide, alone, further impaired renal function while also producing greater glomerular injury [116]. Recently, we have repeated this study in another protocol, and our findings showed only slightly salutary renal effects of hydrochlorothiazide in this experimental model (abstract for AHA council, 2004). The explanation for these seemingly different findings is uncertain but may result from the differences in SHR generations and the consumed $L$ NAME doses, thereby underscoring the importance of having special control groups for all studies.

In summary, although thiazide diuretics are recommended for first-step antihypertensive therapy, their long-term renal effects remain unknown. More experimental and clinical studies are expected.

\section{Conclusion}

This report reviews the pathophysiological renal outcomes and the renal responses of the commonly used antihypertensive agents in chronic nitric-oxide-suppressed rats. Thus, calcium antagonists, ACE inhibitors and ARBs have been demonstrated to prevent and even reverse the adverse renal hemodynamic, glomerular dynamic and renal pathological alterations induced by chronic NOS inhibition. An aldosterone antagonist impressively improved the severe proteinuria and renal histopathological alterations in the absence of any of the renal hemodynamic and glomerular dynamic effects produced by the calcium antagonists or angiotensin II inhibitors in the $L$-NAME/SHR model. These actions, therefore, provide important clinical implications for patients with essential hypertension and other cardiovascular and renal complications or diseases which are commonly associated with NOS deficiency. 


\section{References}

1 Furchgott RF: The 1996 Albert Lasker Medical Research Awards. The discovery of endothelium-derived relaxing factor and its importance in the identification of nitric oxide. JAMA 1996;276:1186-1188.

-2 Moncada S, Higgs A: The $L$-arginine-nitric oxide pathway. N Engl J Med 1993;329:20022012.

-3 Takahashi T: Pathophysiological significance of neuronal nitric oxide synthase in the gastrointestinal tract. J Gastroenterol 2003;38:421430.

4 Kone BC: Nitric oxide synthesis in the kidney: Isoforms, biosynthesis, and functions in health. Semin Nephrol 2004;24:299-315.

-5 Raij L: Workshop: Hypertension and cardiovascular risk factors: Role of the angiotensin II-nitric oxide interaction. Hypertension 2001; 37:767-773.

6 Brand-Schieber E, Pucci M, Nasjletti A: Determinants of renal vasoconstriction after systemic inhibition of nitric oxide synthesis in rats. Am J Physiol 1996;270:R1203-R1207.

7 Kalinowski L, Matys T, Chabielska E, Buczko W, Malinski T: Angiotensin II AT1 receptor antagonists inhibit platelet adhesion and aggregation by nitric oxide release. Hypertension 2002;40:521-527.

-8 Brede M, Roell W, Ritter O, Wiesmann F, Jahns R, Haase A, Fleischmann BK, Hein L: Cardiac hypertrophy is associated with decreased eNOS expression in angiotensin AT2 receptor-deficient mice. Hypertension 2003; 42:1177-1182.

-9 Rizvi MA, Myers PR: Nitric oxide modulates basal and endothelin-induced coronary artery vascular smooth muscle cell proliferation and collagen levels. J Mol Cell Cardiol 1997;29: 1779-1789.

-10 Ono H, Ono Y, Takanohashi A, Matsuoka H, Frohlich ED: Apoptosis and glomerular injury after prolonged nitric oxide synthase inhibition in spontaneously hypertensive rats. Hypertension 2001;38:1300-1306.

11 Zanchi A, Schaad NC, Osterheld MC, Grouzmann E, Nussberger J, Brunner HR, Waeber $B$ : Effects of chronic NO synthase inhibition in rats on renin-angiotensin system and sympathetic nervous system. Am J Physiol 1995;268: H2267-H2273.

12 Wessels J, Peake P, Pussell BA, Macdonald GJ: Nitric oxide synthase inhibition in a spontaneously hypertensive rat model of diabetic nephropathy. Clin Exp Pharmacol Physiol 1997; 24:451-453.

13 Kashiwagi M, Shinozaki M, Hirakata H, Tamaki K, Hirano T, Tokumoto M, Goto $\mathrm{H}$, Kuda S, Fujishima M: Locally activated reninangiotensin system associated with TGF-beta1 as a major actor for renal injury induced by chronic inhibition of nitric oxide synthase in rats. J Am Soc Nephrol 2000;11:616-624.
14 Sander M, Hansen J, Victor RG: The sympathetic nervous system is involved in the maintenance but not initiation of the hypertension induced by $\mathrm{N}$ (omega)-nitro- $L$-arginine methyl ester. Hypertension 1997;30:64-70.

15 Baylis C, Mitruka B, Deng A: Chronic blockade of nitric oxide synthesis in the rat produces systemic hypertension and glomerular damage. J Clin Invest 1992;90:278-281.

16 Ribeiro MO, Antunes E, de Nucci G, Lovisolo SM, Zatz R: Chronic inhibition of nitric oxide synthesis: A new model of arterial hypertension. Hypertension 1992;20:298-303.

17 Ono H, Ono Y, Frohlich ED: Nitric oxide synthesis inhibition in spontaneously hypertensive rats: Systemic, renal, and glomerular hemodynamics. Hypertension 1995;26:249255.

18 Frohlich ED, Arthur C: Corcoran Memorial Lecture: Influence of nitric oxide and angiotensin II on renal involvement in hypertension. Hypertension 1997;29:188-193.

19 Verhagen AM, Koomans HA, Joles JA: Predisposition of spontaneously hypertensive rats to develop renal injury during nitric oxide synthase inhibition. Eur J Pharmacol 2001;411: 175-180.

20 Barbuto N, Almeida JR, Pereira LM, Mandarim-de-Lacerda CA: Renal cortex remodeling in nitric oxide deficient rats treated with enalapril. J Cell Mol Med 2004;8:102-108.

21 Komatsu K, Frohlich ED, Ono H, Ono Y, Numabe A, Willis GW: Glomerular dynamics and morphology of aged SHR. Hypertension 1995;25:207-213.

-22 Dworkin LD, Feiner HD: Glomerular injury in uninephrectomized spontaneously hypertensive rats: A consequence of glomerular capillary hypertension. J Clin Invest 1986;77: 797-809.

23 Dworkin LD, Feiner HD, Parker M, Tolbert E: Effects of nifedipine and enalapril on glomerular structure and function in uninephrectomized SHR. Kidney Int 1991;39:1112-1127.

24 Bidani AK, Griffin KA, Plott W, Schwartz MM: Renal ablation acutely transforms 'benign' hypertension to 'malignant' nephrosclerosis in hypertensive rats. Hypertension 1994; 24:309-316.

-25 Griffin KA, Picken MM, Churchill M, Churchill P, Bidani AK: Functional and structural correlates of glomerulosclerosis after renal mass reduction in the rat. J Am Soc Nephrol 2000;11:497-506.

26 Dworkin LD, Hostetter TH, Rennke HG, Brenner BM: Hemodynamic basis for glomerular injury in rats with desoxycorticosteronesalt hypertension. J Clin Invest 1984;73:14481461.

27 Dworkin LD, Tolbert E, Recht PA, Hersch JC, Feiner H, Levin RI: Effects of amlodipine on glomerular filtration, growth, and injury in experimental hypertension. Hypertension 1996; 27:245-250.
28 Meyer TW, Rennke HG: Progressive glomerular injury after limited renal infarction in the rat. Am J Physiol 1988;254:F856-F862.

29 Loutzenhiser R, Epstein M, Horton C, Sonke $\mathrm{P}$ : Reversal by the calcium antagonist nisoldipine of norepinephrine-induced reduction of GFR: Evidence for preferential antagonism of preglomerular vasoconstriction. J Pharmacol Exp Ther 1985;232:382-387.

-30 Loutzenhiser R, Epstein M, Horton C: Inhibition by diltiazem of pressure-induced afferent vasoconstriction in the isolated perfused rat kidney. Am J Cardiol 1987;59:72A-75A.

- 31 Loutzenhiser RD, Epstein M, Fischetti F, Horton C: Effects of amlodipine on renal hemodynamics. Am J Cardiol 1989;64:122I-127I.

32 Carmines PK, Navar LG: Disparate effects of Ca channel blockade on afferent and efferent arteriolar responses to ANG II. Am J Physiol 1989;256:F1015-F1020.

- 33 Inscho EW, Carmines PK, Cook AK, Navar LG: Afferent arteriolar responsiveness to altered perfusion pressure in renal hypertension. Hypertension 1990;15:748-752.

34 Feng MG, Li M, Navar LG: T-type calcium channels in the regulation of afferent and efferent arterioles in rats. Am J Physiol Renal Physiol 2004;286:F331-F337.

35 Sabbatini M, Leonardi A, Testa R, Vitaioli L, Amenta F: Effects of calcium antagonists on glomerular arterioles in spontaneously hypertensive rats. Hypertension 2000;35:775-779.

-36 Isshiki T, Nishikimi T, Uchino K, Kardon MB, Frohlich ED: Diltiazem reduces glomerular pressure in spontaneously hypertensive rats. Cardiovasc Drugs Ther 1992;6:91-92.

37 Dworkin LD, Levin RI, Benstein JA, Parker M, Ullian ME, Kim Y, Feiner HD: Effects of nifedipine and enalapril on glomerular injury in rats with deoxycorticosterone-salt hypertension. Am J Physiol 1990;259:F598-F604.

38 Dworkin LD, Tolbert E, Recht PA, Hersch JC, Feiner H, Levin RI: Effects of amlodipine on glomerular filtration, growth, and injury in experimental hypertension. Hypertension 1996; 27:245-250.

39 Griffin KA, Picken MM, Bidani AK: Deleterious effects of calcium channel blockade on pressure transmission and glomerular injury in rat remnant kidneys. J Clin Invest 1995;96: 793-800.

40 Griffin KA, Picken MM, Bakris GL, Bidani AK: Class differences in the effects of calcium channel blockers in the rat remnant kidney model. Kidney Int 1999;55:1849-1860.

41 Griffin KA, Picken M, Bakris GL, Bidani AK: Comparative effects of selective T- and L-type calcium channel blockers in the remnant kidney model. Hypertension 2001;37:12681272.

42 Ribeiro MO, Antunes E, Muscara MN, De Nucci G, Zatz R: Nifedipine prevents renal injury in rats with chronic nitric oxide inhibition. Hypertension 1995;26:150-155. 
43 Navarro-Cid J, Maeso R, Rodrigo E, MunozGarcia R, Ruilope LM, Lahera V, Cachofeiro $\mathrm{V}$ : Renal and vascular consequences of the chronic nitric oxide synthase inhibition: Effects of antihypertensive drugs. Am J Hypertens 1996;9:1077-1083.

-44 Akuzawa N, Nakamura T, Kurashina T, Saito Y, Hoshino J, Sakamoto H, Sumino H, Ono Z, Nagai R: Antihypertensive agents prevent nephrosclerosis and left ventricular hypertrophy induced in rats by prolonged inhibition of nitric oxide synthesis. Am J Hypertens 1998; 11:697-707.

-45 Mandarim-de-Lacerda CA, Pereira LM: Renal cortical remodelling by NO-synthesis blockers in rats is prevented by angiotensin-converting enzyme inhibitor and calcium channel blocker. J Cell Mol Med 2001;5:276-283.

-46 Qiu C, Bruneval P, Roeckel A, Heudes D, Duong Van Huyen JP, Roux S: Mibefradil prevents $L$-NAME-exacerbated nephrosclerosis in spontaneously hypertensive rats. J Hypertens 1999; 17:1489-1495.

-47 Watanabe S, Ono H, Ishimitsu T, Matsuoka H, Ono Y, Fujimori T: Calcium antagonist inhibits glomerular cell apoptosis and injuries of $L$ NAME exacerbated nephrosclerosis in SHR. Hypertens Res 2000;23:683-691.

-48 Hayashi K, Ozawa Y, Fujiwara K, Wakino S, Kumagai H, Saruta T: Role of actions of calcium antagonists on efferent arterioles - With special references to glomerular hypertension. Am J Nephrol 2003;23:229-244.

49 Francischetti A, Ono H, Frohlich ED: Renoprotective effects of felodipine and/or enalapril in spontaneously hypertensive rats with and without L-NAME. Hypertension 1998;31: 795-801.

-50 Nakamura Y, Ono H, Frohlich ED: Differential effects of T- and L-type calcium antagonists on glomerular dynamics in spontaneously hypertensive rats. Hypertension 1999;34:273278.

-51 Zhou X, Ono H, Ono Y, Frohlich ED: N- and L-type calcium channel antagonistic effects on glomerular dynamics in $L$-NAME rats. J Hypertens 2002;20:993-1000.

- 52 Susic D, Frohlich ED: Nephroprotective effect of antihypertensive drugs in essential hypertension. J Hypertens 1998;16:555-567.

-53 Taal MW, Brenner BM: Renoprotective benefits of RAS inhibition: From ACEI to angiotensin II antagonists. Kidney Int 2000;57: 1803-1817.

-54 Remuzzi G, Ruggenenti P, Perico N: Chronic renal diseases: Renoprotective benefits of renin-angiotensin system inhibition. Ann Intern Med 2002;136:604-615.

- 55 Rosenberg ME, Smith LJ, Correa-Rotter R, Hostetter TH: The paradox of the renin-angiotensin system in chronic renal disease. Kidney Int 1994;45:403-410.

-56 Ma L, Fogo AB: Role of angiotensin II in glomerular injury. Semin Nephrol 2001;21:544553.

-57 Cao Z, Cooper ME: Role of angiotensin II in tubulointerstitial injury. Semin Nephrol 2001; 21:554-562.
58 Gavras I: Bradykinin-mediated effects of ACE inhibition. Kidney Int 1992;42:1020-1029.

-59 Vanhoutte PM, Boulanger CM, Mombouli JV: Endothelium-derived relaxing factors and converting enzyme inhibition. Am J Cardiol 1995; 76:3E-12E.

60 Hilgers KF, Mann JF: ACE inhibitors versus AT1 receptor antagonists in patients with chronic renal disease. J Am Soc Nephrol 2002; 13:1100-1108.

61 Hornig B, Drexler H: Endothelial function and bradykinin in humans. Drugs 1997;54:42-47.

62 Kon V, Fogo A, Ichikava I: Bradykinin causes selective efferent arteriolar dilatation during angiotensin I converting enzyme inhibition. Kidney Int 1993;44:545-550.

63 Liu YH, Yang XP, Sharov VG, Nass O, Sabbah HN, Peterson E, Carretero OA: Effects of angiotensin-converting enzyme inhibitors and angiotensin II type 1 receptor antagonists in rats with heart failure: Role of kinins and angiotensin II type 2 receptors. J Clin Invest 1997;99:1926-1935.

64 Siragy HM, Carey RM: Protective role of the angiotensin AT2 receptor in a renal wrap hypertension model. Hypertension 1999;33: 1237-1242.

65 Gigante B, Piras O, De Paolis P, Porcellini A, Natale A, Volpe M: Role of the angiotensin II $\mathrm{AT}_{2}$-subtype receptors in the blood pressure lowering effect of losartan in salt-restricted rats. J Hypertens 1999;16:2039-2043.

-66 Nakajima M, Hutchinson HG, Fujinaga M, Hayashida W, Morishita R, Zhang L, Horiuchi M, Pratt RE, Dzau VJ: The angiotensin II type 2 (AT2) receptor antagonizes the growth effects of the AT1 receptor: Gain-of-function study using gene transfer. Proc Natl Acad Sci USA 1995;92:10663-10667.

67 Stoll M, Steckelings UM, Paul M, Bottari SP, Metzger R, Unger T: The angiotensin AT2 receptor mediates inhibition of cell proliferation in coronary endothelial cells. J Clin Invest 1995;95:651-657.

68 Tsuzuki S, Matoba T, Eguchi S, Inagami T: Angiotensin II type 2 receptor inhibits cell proliferation and activates tyrosine phosphatase. Hypertension 1996;28:916-918.

69 Meffert S, Stoll M, Steckelings UM, Bottari SP, Unger T: The angiotensin II $\mathrm{AT}_{2}$ receptor inhibits proliferation and promotes differentiation in PC12W cells. Mol Cell Endocrinol 1996;122:59-67.

70 Maric C, Aldred GP, Harris PJ, Alcorn D: Angiotensin II inhibits growth of cultured embryonic renomedullary interstitial cells through the $\mathrm{AT}_{2}$ receptor. Kidney Int 1998;53:92-96.

71 Kuizinga MC, Smits JFM, Arends JW, Daemen MJAP: AT2 receptor blockade reduces cardiac interstitial cell DNA synthesis and cardiac function after rat myocardial infarction. J Mol Cell Cardiol 1998;30:425-434.

72 Taal MW, Brenner BM: ACE-I vs angiotensin II receptor antagonists: Prevention of renal injury in chronic rat models. J Hum Hypertens 1999;13:S51-S56.
73 Noda M, Fukuda R, Matsuo T, Ohta M, Nagano $\mathrm{H}$, Imura $\mathrm{Y}$, Nishikawa K, Shibouta Y: Effects of candesartan cilexetil (TCV-116) and enalapril in 5/6 nephrectomized rats. Kidney Int 1997;63:S136-S139.

74 Noda M, Matsuo T, Fukuda R, Ohta M, Nagano $\mathrm{H}$, Shibouta $\mathrm{Y}$, Naka T, Nishikawa $\mathrm{K}$, Imura Y: Effect of candesartan cilexetil (TCV$116)$ in rats with chronic renal failure. Kidney Int 1999;56:898-909.

75 Nakao N, Yoshimura A, Morita H, Takada M, Kayano T, Ideura T: Combination treatment of angiotensin-II receptor blocker and angiotensin-converting-enzyme inhibitor in non-diabetic renal disease (COOPERATE): A randomized controlled trial. Lancet 2003;361: 117-124.

76 Mogensen CE, Neldam S, Tikkanen I, Oren S, Viskoper R, Watts RW, Cooper ME: Randomised controlled trial of dual blockade of renin-angiotensin system in patients with hypertension, microalbuminuria, and non-insulin dependent diabetes: The Candesartan and Lisinopril Microalbuminuria (CALM) study. BMJ 2000;321:1440-1444.

-77 Barnett AH, Bain SC, Bouter P, Karlberg B, Madsbad S, Jervell J, Mustonen J: Diabetics Exposed to Telmisartan and Enalapril Study Group: Angiotensin-receptor blockade versus converting-enzyme inhibition in type 2 diabetes and nephropathy. N Engl J Med 2004;351: 1952-1961.

78 Ferrari P, Marti HP, Pfister M, Frey FJ: Additive antiproteinuric effect of combined ACE inhibition and angiotensin II receptor blockade. J Hypertens 2002;20:125-130.

79 Campbell R, Sangalli F, Perticucci E, Aros C, Viscarra C, Perna A, Remuzzi A, Bertocchi F, Fagiani L, Remuzzi G, Ruggenenti P: Effects of combined ACE inhibitor and angiotensin II antagonist treatment in human chronic nephropathies. Kidney Int 2003;63:1094-1103.

-80 Jacobsen P, Andersen S, Rossing K, Hansen BV, Parving HH: Dual blockade of the reninangiotensin system in type 1 patients with diabetic nephropathy. Nephrol Dial Transplant 2002;17:1019-1024.

-81 Jacobsen P, Andersen S, Jensen BR, Parving HH: Additive effect of ACE inhibition and angiotensin II receptor blockade in type I diabetic patients with diabetic nephropathy. J Am Soc Nephrol 2003; 14:992-999.

-82 Ono H, Ono Y, Frohlich ED: ACE inhibition prevents and reverses $L$-NAME-exacerbated nephrosclerosis in spontaneously hypertensive rats. Hypertension 1996;27:176-183.

83 Zhou X, Ono H, Ono Y, Frohlich ED: Aldosterone antagonism ameliorates proteinuria and nephrosclerosis independent of glomerular dynamics in $L$-NAME/SHR model. Am J Nephrol 2004;24:242-249.

84 Nakamura Y, Ono H, Zhou X, Frohlich ED: Angiotensin type 1 receptor antagonism and ACE inhibition produce similar renoprotection in $L$-NAME/SHR rats. Hypertension 2001;37:1092-1097. 
>85 Hropot M, Grotsch H, Klaus E, Langer KH, Linz W, Wiemer G, Scholkens BA: Ramipril prevents the detrimental sequels of chronic NO synthase inhibition in rats: Hypertension, cardiac hypertrophy and renal insufficiency. Naunyn Schmiedebergs Arch Pharmacol 1994; 350:646-652.

-86 Michel JB, Xu Y, Blot S, Philippe M, Chatellier G: Improved survival in rats administered $\mathrm{N}^{\mathrm{G}}$-nitro- $L$-arginine methyl ester due to converting enzyme inhibition. J Cardiovasc Pharmacol 1996;28:142-148.

>87 Nakamura T, Kurashina T, Saito Y, Sumino H, Akuzawa N, Aizawa H, Sakamoto H, Ono Z, Nagai R: $E_{\mathrm{A}}$ receptor antagonist ameliorates nephrosclerosis and left ventricular hypertrophy induced in rat by prolonged inhibition of nitric oxide synthesis. Hypertens Res 1998;21:251-257.

-88 Ribeiro MO, Antunes E, de Nucci G, Lovisolo SM, Zatz R: Chronic inhibition of nitric oxide synthesis: A new model of arterial hypertension. Hypertension 1992;20:298-303.

-89 Jover B, Herizi A, Ventre F, Dupont M, Mimran A: Sodium and angiotensin in hypertension induced by long-term nitric oxide blockade. Hypertension 1993;21:944-948.

$\checkmark 90$ Verhagen AM, Braam B, Boer P, Grone HJ, Koomans HA, Joles JA: Losartan-sensitive renal damage caused by chronic NOS inhibition does not involve increased renal angiotensin II concentrations. Kidney Int 1999;56:222-231.

-91 Kashiwagi M, Shinozaki M, Hirakata H, Tamaki K, Hirano T, Tokumoto M, Goto H, Okuda S, Fujishima M: Locally activated renin-angiotensin system associated with TGFbeta 1 as a major factor for renal injury induced by chronic inhibition of nitric oxide synthase in rats. J Am Soc Nephrol 2000;11:616-624.

-92 Blasi ER, Rocha R, Rudolph AE, Blomme EA, Polly ML, McMahon EG: Aldosterone/salt induces renal inflammation and fibrosis in hypertensive rats. Kidney Int 2003;63:17911800.

-93 Greene EL, Kren S, Hostetter TH: Role of aldosterone in the remnant kidney model in the rat. J Clin Invest 1996;98:1063-1068.

>94 Rocha R, Chander PN, Khanna K, Zuckerman A, Stier CT Jr: Mineralocorticoid blockade reduces vascular injury in stroke-prone hypertensive rats. Hypertension 1998;31:451-458.

-95 Rocha R, Chander PN, Zuckerman A, Stier CT Jr: Role of aldosterone in renal vascular injury in stroke-prone hypertensive rats. Hypertension 1999;33:232-237.

$\checkmark 96$ Rocha R, Stier CT Jr, Kifor I, Ochoa-Maya MR, Rennke HG, Williams GH, Adler GK: Aldosterone: A mediator of myocardial necrosis and renal arteriopathy. Endocrinology 2000; 141:3871-3878.
-97 Brown NJ, Nakamura S, Ma L, Nakamura I, Donnert E, Freeman M, Vaughan DE, Fogo $\mathrm{AB}$ : Aldosterone modulates plasminogen activator inhibitor-1 and glomerulosclerosis in vivo. Kidney Int 2000;58:1219-1227.

-98 Hene RJ, Boer P, Koomans HA, Mees EJ: Plasma aldosterone concentrations in chronic renal disease. Kidney Int 1982;21:98-101.

$\checkmark 99$ White WB, Duprez D, St Hillaire R, Krause S, Roniker B, Kuse-Hamilton J, Weber MA: Effects of the selective aldosterone blocker eplerenone versus the calcium antagonist amlodipine in systolic hypertension. Hypertension 2003;41:1021-1026.

100 Epstein M, Buckalew V Jr, Martinez F, Altamirano J, Roniker B, Kleiman J, Krause S: Antiproteinuric efficacy of eplerenone, enalapril, and eplerenone/enalapril combination therapy in diabetic hypertensives with microalbuminuria. Am J Hypertens 2002;15:24A.

101 Sato A, Suzuki Y, Shibata H, Saruta T: Plasma aldosterone concentrations are not related to the degree of angiotensin-converting enzyme inhibition in essential hypertensive patients. Hypertens Res 2000;23:25-31.

102 Struthers AD: Aldosterone escape during angiotensin-converting enzyme inhibitor therapy in chronic heart failure. J Card Fail 1996; 2:47-54.

103 Shiigai T, Shichiri M: Late escape from the antiproteinuric effect of ACE inhibitors in nondiabetic renal disease. Am J Kidney Dis 2001;37:477-483.

104 Sato A, Hayashi K, Naruse M, Saruta T: Effectiveness of aldosterone blockade in patients with diabetic nephropathy. Hypertension 2003;41:64-68.

105 Epstein M: Aldosterone as a mediator of progressive renal disease: Pathogenetic and clinical implications. Am J Kidney Dis 2001;37: 677-688.

106 Epstein M: Aldosterone and the hypertensive kidney: Its emerging role as a mediator of progressive renal dysfunction: A paradigm shift. J Hypertens 2001;19:829-842.

107 Pitt B, Zannad F, Remme WJ, Cody R, Castaigne A, Perez A, Palensky J, Wittes J: The effect of spironolactone on morbidity and mortality in patients with severe heart failure. N Engl J Med 1999;341:709-717.

108 Pitt B, Remme W, Zannad F, Neaton J, Martinez F, Roniker B, Bittman R, Hurley S, Kleiman J, Gatlin M: Eplerenone, a selective aldosterone blocker, in patients with left ventricular dysfunction after myocardial infarction. N Engl J Med 2003;348:1309-1321.

109 Usui M, Ichiki T, Katoh M, Egashira K, Takeshita A: Regulation of angiotensin II receptor expression by nitric oxide in rat adrenal gland. Hypertension 1998;32:527-533.
110 Freis E, Wilson IM: Potentiating effect of chlorothiazide (Diuril) in combination with antihypertensive agents: Preliminary report. Med Ann Dist Columbia 1957;26:468.

111 ALLHAT Officers and Coordinators for the ALLHAT Collaborative Research Group: Major outcomes in high-risk hypertensive patients randomized to angiotensin-converting enzyme inhibitor or calcium channel blocker vs diuretic: The Antihypertensive and LipidLowering Treatment to Prevent Heart Attack Trial (ALLHAT). JAMA 2002;288:29812997.

112 Wing LM, Reid CM, Ryan P, Beilin LJ, Brown MA, Jennings GL, Johnston CI, McNeil JJ, Macdonald GJ, Marley JE, Morgan TO, West MJ, Second Australian National Blood Pressure Study Group: A comparison of outcomes with angiotensin-converting enzyme inhibitors and diuretics for hypertension in the elderly. N Engl J Med 2003;348: 583-592.

113 Chobanian AV, Bakris GL, Black HR, Cushman WC, Green LA, Izzo JL Jr, Jones DW, Materson BJ, Oparil S, Wright JT Jr, Roccella EJ, National Heart, Lung, and Blood Institute Joint National Committee on Prevention, Detection, Evaluation, and Treatment of High Blood Pressure, National High Blood Pressure Education Program Coordinating Committee: The Seventh Report of the Joint National Committee on Prevention, Detection, Evaluation, and Treatment of High Blood Pressure: The JNC 7 report. JAMA 2003;289:2560-2572.

114 Collins R, Peto R, MacMahon S, Hebert P, Fiebach NH, Eberlein KA, Godwin J, Qizilbash N, Taylor JO, Hennekens CH: Blood pressure, stroke, and coronary heart disease. 2. Short-term reductions in blood pressure: Overview of randomised drug trials in their epidemiological context. Lancet 1990;335: 827-838.

115 Benstein JA, Feiner HD, Parker M, Dworkin LD: Superiority of salt restriction over diuretics in reducing renal hypertrophy and injury in uninephrectomized SHR. Am J Physiol 1990;258:F1675-F1681.

116 Ono Y, Ono H, Frohlich ED: Hydrochlorothiazide exacerbates nitric oxide blockade nephrosclerosis with glomerular hypertension in spontaneously hypertensive rats. $\mathrm{J} \mathrm{Hy-}$ pertens 1996;14:823-828.

117 de Leeuw PW: Renal function in the elderly: Results from the European Working Party on High Blood Pressure in the Elderly trial. Am J Med 1991;90:45S-49S. 